\title{
Editorial
}

\section{Ocular trauma: prevention}

Eli Pradhan

Ocular trauma is an important cause of unilateral visual impairment worldwide. According to Nepal blindness survey (Brillinat et al, 1985), it accounted for $2.4 \%$ of blindness, and in another community based study (Upadhyay $\mathrm{M}$ et al, 2001), the prevalence of ocular trauma was observed to be $0.7 \%$. The Bhaktapur Eye Study confirms that "corneal trauma leading to ulceration" is the second most common cause of blindness after cataract in Nepal.

Most of the ophthalmologists come across the patients with injury to the eye, which could range from small epithelial erosion to ruptured globe. Therefore, visual outcome would vary from very minimal effect to profound loss with significant socioeconomic and psychological impact (Nordber E, 2000; E Pradhan et al, 2000). However, with the use of new technologies and the immediate intervention, the burden of the aftereffect could be minimized.

The workplaces, home, recreational activities, road traffic accidents and physical assaults are the common causes of eye injuries for all age groups. However, the significant age group affected by trauma is the pediatric population and the damage is rather serious (Werner, 1952; Shreard RM, 2007; Hosseini H, 2011). It is a leading cause of non-congenital unilateral blindness in this age group. Nevertheless, most ocular injuries in children are preventable (Saxena et al, 2002), irrespective of causative agents or the site of occurrence. Often with such injuries, parental education or the adult supervision seems to be an important means of preventative medicine. In order to provide such education to parents, ophthalmologists must remind themselves as to the several factors related to pediatric trauma that are most pertinent to prevention of ocular trauma.

More than 65,000 work-related eye injuries and illness are reported in the United States annually [Peate, W,F, 2007]. In less developed country, it accounted for $8 \%$ of all occupational injuries as recorded in selected hospitals [Yu, T.S.I et al, 2004]. A study in China ( Cai, M.and Zhang, J, 2015) indicated that male worker, low education level, lack of safety training, without machine guarding and eye protection were significant risk factors for occupational injuries. A Work-Related Injury Statistics Query System is established in developed countries like the US [Xiang, $\mathrm{H}$ et al, 2005]. However, many developing countries, including Nepal do not require employers or health care providers to report preventable injuries. Therefore, an ocular trauma databank, for further epidemiologic studies would be very useful.

Occupational injuries are largely avoidable particularly if adequate eye protection is used and appropriate machine securities are placed over obvious hazards (Lipscomb, 2000; NORA 1998). The eye protection devices could reduce the risk of work-related 
eye injury by up to $60 \%$, however only $18.4 \%$ of workers were wearing eye protection devices when injured [Chen S.Y et al, 2009]

Similarly, an implementation of seat-belt legislation and use of redesigned airbags in vehicles have significantly reduced the number of ocular injuries in cases of road traffic accidents (Johnston and Armstrong, 1986; Lehto KS et al, 2003). Therefore, knowledge of the causes of eye injuries can aid in guiding preventative strategies and optimizing management capacity.

The sports related injuries are more common in developed counties [ Leivo $\mathrm{T}$ et al, 2015; Kim T Et al, 2011; Maxen $M$ et al, 2011]. In order to prevent the damage, the protective eyewear during the activities is very effective [Leivo T et al, 2015; Bro T and Ghosh F, 2016] and should be mandatory in all age groups.

In conclusion, the prevention of ocular injury and trauma is an important topic but it is often a neglected part of the discussion. Therefore a mass awareness, trauma related education to children and their parents, factory workers, farmers is very important aspect of prevention of catastrophic effect of trauma to the eye and reduction of ocular morbidity and prevalence of blindness.

\section{References}

Brilliant LB, Pokharel RP, Grasset NC, et al (1985). Epidemiology of blindness in Nepal. Bulletin of the World Health Organization ; 63:375-386.

Bro T and Ghosh F. (2016). Floorball-related eye injuries: The impact of protective eyewear. Scandinavian Journal of Medicine \& Science in Sports. doi: 10.1111/sms. 12653

Cai M and Zhang J (2015). Epidemiological Characteristics of Work-Related Ocular Trauma in Southwest Region of China. Int. J. Environ. Res. Public Health; 12: 9864-9875

Chen SY, Fong PC, Lin SF et al (2009). A case-crossover study on transient risk factors of work-related eye injuries. Occup. Environ. Med; 66: 517-522.

Hosseini H, Masoumpour M, Keshavarz-Fazl F, et al (2011). Clinical and epidemiologic characteristics of severe childhood ocular injuries in Southern Iran. Middle East Afr J Ophthalmol;18:136-40.

Johnston PB, Armstrong MF (1986). Eye injuries in Northern Ireland two years after seat belt. Br J Ophthalmol; 70:460-2

Kim T, Nunes AP, Mello MJ, et al (2011): Incidence of sports-related eye injuries in the United States: 2001-2009. Graefes Arch Clin Exp Ophthalmol; 249: 1743-1744

Lehto KS, Sulander PO, Tervo TMT (2003). Do motor vehicle airbags increase risk of ocular injuries in adults? Ophthalmology;110(6):1082-1088. doi:10.1016/S0161-6420(03)00244-6.

Leivo T, Haavisto AK, Sahraravand A (2015). Sports-related eye injuries: the current picture. Acta Ophthalmol; 93(3):224-31. doi: 10.1111/aos.12633.

Lipscomb HJ (2000). Effectiveness of interventions to prevent work-related eye injuries. Am J Prev Med;18:27-33. 
Maxen M, Kuhl S, Krastl G, et al (2011): Eye injuries and orofacial traumas in floorball - a survey in Switzerland and Sweden. Dent Traumatol; 27: 95-101.

NIOSH National Occupational Research Agenda (NORA). Report on traumatic occupational injury research needs and priorities. US Department of Health and Human Services, Public Health Service, CDC, 1998. DHHS (NIOSH) publication no 98-134.

Nordber E (2000). Ocular injuries as a public health problem in sub-Saharan Africa: Epidemiology and prospect for control. East Afr Med J; 77:1 - 43.

Peate WF (2007). Work-related eye injuries and illness. Am. Fam. Physician; 75, 1017-1022.

Pradhan E, Shakya S, Koirala S et al (2000). Journal of the society of surgeons Nepal; 2000, 3. 6-11

Saxena R, Sinha R, Purohit A, Dada T, Vajpayee RB, Azad RV (2002). Pattern of pediatric ocular trauma in India. Indian J Pediatr; 69 (10):863-7.

Sheard RM, Mireskandari K, Ezra E, et al (2007). Vitreoretinal surgery after childhood ocular trauma. Eye (Lond);21:793-8.

Upadhyay M, P Karmacharya P, S Koirala S, et al (2001) Bhaktapur eye study: ocular trauma and antibiotic prophylaxis for the prevention of corneal ulceration in Nepal. Br J Ophthalmol; 85:388-92.

Werner S (1952). On injuries to the eyes in children. Acta Opthalmol; 30: 97-104

Xiang, H.; Stallones, L.; Chen, G et al (2005). Work-related eye injuries treated in hospital emergency departments in the US. Am. J. Ind. Med; 48, 57-62.

Yu, T.S.I.; Liu, H.J.; Hui, K (2004). A Case-Control Study of Eye Injuries in the Workplace in Hong Kong. Ophthalmology; 111, 70-74. 